\title{
Variation in the leaf sodium content of the Hordeum vulgare (barley) cultivar Maythorpe and its derived mutant cv. Golden Promise
}

\author{
B. P. FORSTER*, H. PAKNIYAT, M. MACAULAY, W. MATHESON, M. S. PHILLIPS, \\ W. T. B. THOMAS \& W. POWELL \\ Scottish Crop Research Institute, Invergowrie, Dundee DD2 5DA, U.K.
}

\begin{abstract}
Tests for shoot and root sodium content were carried out on various barley cultivars (Hordeum vulgare) and experimental lines including wild barley (H. spontaneum) and derivatives. Lines were grown in hydroculture with and without the addition of salt $(\mathrm{NaCl})$, and sodium concentrations in shoots and roots were determined. Variation in shoot sodium content was found between the various lines; in contrast, no significant differences were found between the lines tested for root sodium content. The most significant finding was the variation in shoot sodium content between the two cultivars Golden Promise and Maythorpe. Golden Promise is a direct $\gamma$-ray induced mutant of the cultivar Maythorpe and the reduced shoot sodium content of Golden Promise can be attributed to radiation treatment.
\end{abstract}

Keywords: barley, $\gamma$-ray, Hordeum vulgare, mutant, salt tolerance.

\section{Introduction}

The genetic control of salt tolerance in the Triticeae is known to be affected by a number of genes. Indeed, all seven homoeologous chromosome groups of the Triticeae have been implicated in salt tolerance studies (Forster, 1992). The Triticeae contain a number of important small grain cereal crops, bread wheat, macaroni wheat, barley, rye and triticale (the synthetic wheat/rye hybrid). Although some major developmental genes, such as the vernalization requirement genes $(V r n)$ and the photoperiod requirement genes $(P p d)$ have been shown to have pleiotropic effects on salt tolerance in the Triticeae (Taeb et al., 1992), they represent only a small portion of the total genetic variation for this character.

Barley is considered to be the most salt-tolerant crop species in the Triticeae (Maas et al., 1977; Gill \& Dutt, 1987). Genes for salt tolerance have been located to homoeologous chromosomes 1, 4, 5, 6 and 7 in cultivated barley, Hordeum vulgare and a wild relative, $H$. chilense (Forster et al., 1990), thus confirming the polygenic nature of this trait. The results reported here represent some of our continuing work in mapping quantitative trait loci (QTLs) for salt tolerance more

\footnotetext{
${ }^{*}$ Correspondence.
}

precisely in barley. One strategy is to test doubled haploid populations (DHs) of barley which segregate for salt tolerance. For this it is necessary to select a parental combination which shows disparate tolerance to salt; the respective doubled haploid population is then screened for salt tolerance and genetic effects determined by analysis of the marker loci associated with this trait. In the Poaceae, of which the Triticeae is a subtribe, there is a general relationship between low sodium accumulation and salt tolerance (Greenway \& Munns, 1980; Gorham et al., 1985). We describe the shoot and root sodium contents of a number of barley lines which have been used in the development of DHs. Shoot sodium ion $\left(\mathrm{Na}^{+}\right)$content was measured in plants grown in control (no added salt, $\mathrm{NaCl}$ ) and saline ( 150 or $175 \mathrm{~mol} \mathrm{~m}^{-3}$ added $\mathrm{NaCl}$ ) hydroculture. The line HS26/55C proved interesting and was investigated further.

HS26/55C was developed from a cross between $\mathrm{cv}$. Golden Promise and a wild barley ( $H$. spontaneum, HS26) in an attempt to introgress mildew resistance into Golden Promise from the wild species (Thomas et al., 1988; Fig. 1).

The results presented in this paper indicate that the low shoot sodium accumulation of $\mathrm{HS} 26 / 55 \mathrm{C}$ is inherited from Golden Promise and not from the wild species. Golden Promise is an interesting cultivar in 


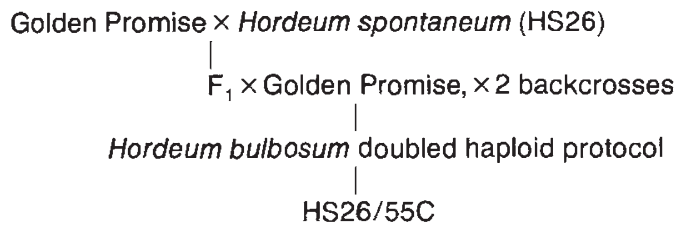

Fig. 1 Pedigree of the mildew-resistant doubled haploid line, HS26/55C.

that it was produced by $\gamma$-ray irradiation of Maythorpe seed. Several mutant lines were produced, one (759/4), was selected for its short, stiff straw, good yield and malting qualities and was developed into the cultivar Golden Promise (Miln Masters, described in Sigurbjornsson \& Micke, 1969).

We provide evidence that the low shoot sodium accumulation of Golden Promise is a product of the $\gamma$-ray irradiation treatment.

\section{Materials and methods}

\section{Plant material}

Twenty-two barley genotypes were studied: 13 cultivars (Hordeum vulgare) - Apex, Blenheim, Dissa, Gerbel, Golden Promise, Goldthorpe, Grit, Heriot, Igri, Maja, Maythorpe, Prisma, Sabarlis; three SCRI breeding lines (H. vulgare) - E224/3, TS264/22, TS $42 / 3 / 5$; one morphological marker stock $(H$. vulgare) - R23; three wild barley selections ( $H$. spontaneum) - HS26 (AFRC collection), HS10 and HS16 (described in Chalmers et al., 1992). The SCRI barley doubled haploid line HS26/55C was also tested.

\section{Sodium accumulation tests}

Plants were grown in three separate experiments. The tests involved growing plants in hydroculture with or without the addition of salt $(\mathrm{NaCl})$. The technique was essentially that described by Forster et al. (1990) with the following amendments: single grains were germinated in $10 \mathrm{~cm} \times 1.5 \mathrm{~cm}$ (diameter) tubes (Sarstedt) filled with vermiculite. These were suspended in hydroculture tanks so that the seed lay $1 \mathrm{~cm}$ above the hydroculture solution and $5 \mathrm{~cm}$ from the bottom of the tube. These tubes were organized in a randomized block design. A $1 \mathrm{~cm}$ hole cut at the bottom of the tubes allowed roots to grow out into the hydroponic solution. Two weeks after germination, salt was added to half the tanks in daily increments of $25 \mathrm{~mol} \mathrm{~m}^{-3}$ $\mathrm{NaCl}$ until the final test concentrations of 0 and 150 or $175 \mathrm{~mol} \mathrm{~m}^{-3}$ of added $\mathrm{NaCl}$ were reached. Calcium chloride, $\mathrm{CaCl}_{2}$, was also added to maintain a ratio between $\mathrm{NaCl}$ and $\mathrm{CaCl}_{2}$ of $20: 1$. Nutrients in the form
Table 1 Mean shoot sodium contents of various barley parental lines grown at 0 and $175 \mathrm{~mol} \mathrm{~m}^{-3}$ added $\mathrm{NaCl}$ from Experiment 1

\begin{tabular}{lcc}
\hline & \multicolumn{2}{c}{ Shoot sodium content $(\mathrm{mg} \mathrm{Na} / \mathrm{g} \mathrm{dry}$ weight $)$} \\
\cline { 2 - 3 } Genotype & $0 \mathrm{~mol} \mathrm{~m}^{-3} \mathrm{NaCl}$ & $175 \mathrm{~mol} \mathrm{~m}^{-3} \mathrm{NaCl}$ \\
\hline Grit & 0.7 & 19.7 \\
Igri & 0.6 & 30.4 \\
Blenheim & 1.2 & 17.0 \\
E224/3 & 0.4 & 20.7 \\
TS264/22 & 0.4 & 42.5 \\
Prisma & 0.4 & 24.3 \\
Apex & 0.6 & 33.5 \\
TS42/3/5 & 1.1 & 18.1 \\
Dissa & 0.4 & 26.3 \\
Sabarlis & 0.4 & 29.6 \\
Gerbel & 0.4 & 11.5 \\
Heriot & 0.7 & 21.6 \\
R23 & 0.4 & 51.1 \\
HS26/55C & 0.4 & 15.5 \\
HS10 & 0.4 & 20.3 \\
HS16 & 0.6 & 29.8 \\
LSD 5\% & NS & 16.75 \\
\hline
\end{tabular}

Doubled haploid populations have been produced between Igri $\times$ Grit, Blenheim $\times$ E224/3, Blenheim $\times$ TS264/22, Apex $\times$ TS42/3/5, Dissa $\times$ Sabarlis and R23 $\times$ HS26/55C.

of $12.87 \mathrm{~g} \mathrm{~L}^{-1}$ Phostrogen (ICI) were added to all tanks. No vernalization treatment was given. The tests were terminated 4-6 weeks after the final salt concentrations were reached, and shoot and root sodium contents and fresh and dry weights were measured. The experiments were carried out in heated glasshouses $\left(16-24^{\circ} \mathrm{C}\right.$ ) either with natural lighting (Experiments 2 and 3 ) or, in the case of winter months (Experiment 1), with supplementary lighting provided by high pressure sodium lamps $\left(300 \mu \mathrm{mol} \mathrm{m}^{-2} \mathrm{~s}^{-1}\right.$, for 16 h daily).

\section{Experiment 1}

In this initial experiment several parental lines used in genetic mapping studies at SCRI were screened for shoot sodium content. Three plants of each line were grown without salt and three were grown at $175 \mathrm{~mol}$ $\mathrm{m}^{-3}$ of added $\mathrm{NaCl}$. Each treatment was replicated twice, that is, with six plants in total for each treatment. The lines used and their shoot $\mathrm{Na}^{+}$contents at harvest are given in Table 1 . Shoot $\mathrm{Na}^{+}$was measured 6 weeks after the final salt concentration was reached. 


\section{Experiment 2}

This experiment was designed to find which parent of HS26/55C, the cultivar Golden Promise or the wild barley selection HS26, contributed more to its low shoot $\mathrm{Na}^{+}$character. These three lines were grown in 0 and $175 \mathrm{~mol} \mathrm{~m}^{-3}$ added $\mathrm{NaCl}$. Results for shoot $\mathrm{Na}^{+}$, measured 4 weeks after the final salt concentration was reached, are given in Table 2 .

\section{Experiment 3}

This experiment was designed to locate the origin of the relatively low shoot $\mathrm{Na}^{+}$of Golden Promise, the pedigree of which is given in Fig. 2. Golden Promise was tested against its parent, Maythorpe, and its grandparents, Goldthorpe and Maja. R23, HS26/55C and HS26 were included as controls. The experimental design consisted of four tubs, two control and two salted ( 0 and $150 \mathrm{~mol} \mathrm{~m}^{-3}$ added $\mathrm{NaCl}$, respectively), with three plants of each genotype in each tub. Results for shoot and root $\mathrm{Na}^{+}$, measured 4 weeks after the final salt concentration was reached, are given in Table 3 .

Table 2 Mean shoot sodium content of HS26/55C, HS26 and Golden Promise grown in Experiment 2

\begin{tabular}{lcc}
\hline & \multicolumn{2}{c}{$\begin{array}{c}\text { Mean shoot sodium content } \\
\text { (mg Na/g dry weight) }\end{array}$} \\
\cline { 2 - 3 } Genotype & $0 \mathrm{~mol} \mathrm{~m}^{-3} \mathrm{NaCl}$ & $175 \mathrm{~mol} \mathrm{~m}^{-3} \mathrm{NaCl}$ \\
\hline HS26 & 2.18 & $54.75^{\mathrm{a}}$ \\
HS26/55C & 1.29 & $23.63^{\mathrm{b}}$ \\
Golden Promise & 1.91 & $21.81^{\mathrm{b}}$ \\
LSD 5\% & $\mathrm{NS}$ & 12.07 \\
\hline
\end{tabular}

Numbers followed by different letters are significantly different from each other.

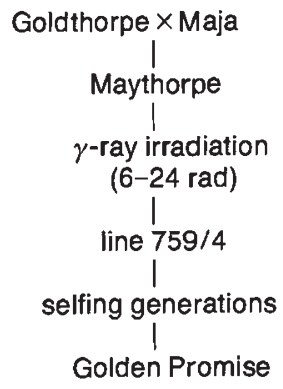

Fig. 2 Pedigree of Golden Promise.

\section{Dry weights and sodium contents}

At harvest each plant was washed in distilled water to remove any external salt. Plants were divided into roots and shoots, which were placed separately in clean polythene bags and freeze-dried (Birchover Instruments) for 5 days. Each sample was then crushed within its bag and placed into clear dry silica crucibles and ovendried overnight at $85^{\circ} \mathrm{C}$ after which dry weights were determined. The dried samples were ignited in a silicalined Carbolite furnace at $450^{\circ} \mathrm{C}$ in a slow stream of oxygen $\left(100 \mathrm{~mL} \mathrm{~min}^{-1}\right)$ for $9 \mathrm{~h}$. The ashed samples were cooled in a desiccator for $30 \mathrm{~min}$, weighed and dissolved in $5 \mathrm{~mL} 6 \mathrm{~N} \mathrm{HCl}$ and $1 \mathrm{~mL} 6 \mathrm{~N} \mathrm{HNO}_{3}$. The crucibles were then heated on a water bath until the samples were dry. The residue was dissolved in $1 \mathrm{~mL}$ $6 \mathrm{~N} \mathrm{HCl}$ with $5 \mathrm{ml}$ deionized distilled water and filtered through Whatman No. 114 filter paper, washed, and made up to $25 \mathrm{~mL}$ with deionized water. The solutions obtained were analysed for sodium using an ARL 3510 ICP Spectrometer using ARL software with a program designed at SCRI (NASALINE). This program uses two emission line wavelengths $(588.995 \mathrm{~nm}$ and $589.592 \mathrm{~nm}$ ) where the interference from other element emissions is low: agreement in the figures produced by the two lines provides an indication that the correct level of sodium is measured.

\section{Data analysis}

All data were subjected to an analysis of variance. Examination of $\mathrm{Na}^{+}$contents showed marked differences in means and variances when comparing salt treatments and control treatments and consequently the treatments were analysed separately.

Table 3 Mean shoot and root sodium contents from Experiment 3

\begin{tabular}{lccccc}
\hline & \multicolumn{2}{c}{ Sodium content $(\mathrm{mg} \mathrm{Na} / \mathrm{g}$ dry weight $)$} \\
\cline { 2 - 3 } & \multicolumn{2}{c}{$0 \mathrm{~mol} \mathrm{~m}^{-3} \mathrm{NaCl}$} & & \multicolumn{2}{c}{$150 \mathrm{~mol} \mathrm{~m}^{-3} \mathrm{NaCl}$} \\
\cline { 2 - 3 } \cline { 5 - 6 } Genotype & Root & Shoot & & Root & Shoot \\
\hline Golden Promise & $0.78^{\mathrm{a}}$ & $0.17^{\mathrm{a}}$ & & 20.69 & $9.20^{\mathrm{a}}$ \\
Maythorpe & $0.56^{\mathrm{a}}$ & $0.20^{\mathrm{a}}$ & & 21.40 & $12.98^{\mathrm{b}}$ \\
Maja & $0.45^{\mathrm{a}}$ & $0.16^{\mathrm{a}}$ & & 23.22 & $12.11^{\mathrm{b}}$ \\
Goldthorpe & $0.76^{\mathrm{a}}$ & $0.15^{\mathrm{a}}$ & & 23.36 & $13.74^{\mathrm{b}}$ \\
R23 & $0.57^{\mathrm{a}}$ & $0.15^{\mathrm{a}}$ & & 25.20 & $14.46^{\mathrm{b}}$ \\
HS26/55C & $1.73^{\mathrm{b}}$ & $0.22^{\mathrm{a}}$ & & 23.09 & $11.48^{\mathrm{a}}$ \\
HS26 & $0.60^{\mathrm{a}}$ & $0.24^{\mathrm{b}}$ & & 19.42 & $21.58^{\mathrm{c}}$ \\
LSD 5\% & 0.65 & 0.08 & & $\mathrm{NS}$ & 3.68 \\
\hline
\end{tabular}

Numbers followed by different letters are significantly different from each other. 


\section{Results and Discussion}

From the results of Experiment 1 (Table 1) it can be seen that a range of shoot $\mathrm{Na}^{+}$content values was found in the 15 barley genotypes screened at $175 \mathrm{~mol} \mathrm{~m}^{-3}$ added $\mathrm{NaCl}$, but no significant variation could be detected in the entries in the control treatments. The lines R23 and Gerbel represent the two extremes for shoot $\mathrm{Na}^{+}$, having the highest and lowest recorded values, respectively. $\mathrm{HS} 26 / 55 \mathrm{C}$ was found to have the second lowest shoot $\mathrm{Na}^{+}$concentration. This was an interesting result as a $\mathrm{DH}$ population between R23 and HS26/55C has been developed at SCRI and can be exploited in locating QTLs controlling shoot $\mathrm{Na}^{+}$uptake and other traits involved in salt tolerance. R23 is a morphological marker stock and studies of biochemical markers show several differences between R23 and HS26/55C (authors' unpublished data); it may therefore be concluded that much genetic polymorphism exists between these two lines, which is an advantage in screening for markers linked to salt tolerance genes.

Experiment 2 was designed to find out which parent contributed more to the relatively low shoot $\mathrm{Na}^{+}$ character of HS26/55C. From Table 2 it can be seen that the $\mathrm{Na}^{+}$content of $\mathrm{HS} 26 / 55 \mathrm{C}$ was not significantly different from that in Golden Promise. In contrast, the selection from the wild population (genotype HS26) contained over twice (significantly more, $P<0.001$ ) the amount of shoot sodium after 4 weeks of exposure to hydroculture containing $175 \mathrm{~mol} \mathrm{~m}^{-3}$ $\mathrm{NaCl}$. It is therefore concluded that the ability of HS26/55C to maintain a relatively low shoot sodium concentration was inherited from Golden Promise and not the $H$. spontaneum selection HS26. This therefore rules out the possibility that the low shoot $\mathrm{Na}^{+}$is associated with the mildew resistance gene introgressed from HS26.
In Experiment 3, lines involved in the pedigrees of Golden Promise and HS26/55C are compared. Although Maythorpe has a similar shoot sodium content to its parental lines Goldthorpe and Maja, there is a significant difference $(P<0.05)$ in shoot $\mathrm{Na}^{+}$content at $150 \mathrm{~mol} \mathrm{~m}^{-3} \mathrm{NaCl}$ between Maythorpe and Golden Promise (Table 3). Since Golden Promise is a direct mutation of Maythorpe it is concluded that the significantly lowered shoot $\mathrm{Na}^{+}$content of salt-stressed Golden Promise is a result of $\gamma$-ray irradiation. If the absolute shoot $\mathrm{Na}^{+}$amount $(\mathrm{mg}$ per $\mathrm{g} \times$ fresh weight; Tables 3 and 4 ) is calculated, Golden Promise is found to have $28 \mathrm{mg} \mathrm{Na}^{+}$per shoot, almost 50 per cent less than Maythorpe, which has $53.87 \mathrm{mg} \mathrm{Na}^{+}$per shoot, despite the fact that Golden Promise is smaller (assuming a constant moisture content). The low shoot $\mathrm{Na}^{+}$content of Golden Promise cannot therefore be explained by a dilution effect. The major morphological difference between these two cultivars is that of stature, Golden Promise having shorter and stiffer straw. This character is attributed to the Golden Promise dwarfing gene (GPert) located on barley chromosome 7 (5H) (Thomas et al., 1984). Other developmental genes, notably vernalization $(V r n)$ and photoperiodic $(P p d)$ genes have been implicated in shoot sodium accumulation in the Triticeae (Taeb et al., 1992). There is therefore a possibility that the reduced shoot sodium accumulation of Golden Promise is a pleiotropic effect of GPert. One of the entries in Experiment 1 (TS42/3/5) also possesses the GPert gene and it shows a low level of shoot $\mathrm{Na}^{+}$(Table 1), but other entries also show similar levels. This provides some further evidence that the low concentration of shoot $\mathrm{Na}^{+}$is associated with GPert, but also suggests that this character may be modified by the genetic background. Further studies of a range of GPert cultivars and populations segregating for the gene are planned to reveal the genetic architecture of the

Table 4 Mean shoot and root fresh weights of lines tested in Experiment 3

\begin{tabular}{|c|c|c|c|c|}
\hline \multirow[b]{2}{*}{ Genotype } & \multicolumn{2}{|c|}{ Shoot fresh weight $(\mathrm{g})$} & \multicolumn{2}{|c|}{ Root fresh weight $(\mathrm{g})$} \\
\hline & $0 \mathrm{~mol} \mathrm{~m}^{-3} \mathrm{NaCl}$ & $150 \mathrm{~mol} \mathrm{~m}^{-3} \mathrm{NaCl}$ & $0 \mathrm{~mol} \mathrm{~m}^{-3} \mathrm{NaCl}$ & $150 \mathrm{~mol} \mathrm{~m}^{-3} \mathrm{NaCl}$ \\
\hline Golden Promise & 12.58 & 3.05 & 3.11 & 0.70 \\
\hline Maythorpe & 13.64 & 4.15 & 4.51 & 0.71 \\
\hline Maja & 19.83 & 3.31 & 6.33 & 0.78 \\
\hline $\mathrm{HS} 26 / 55 \mathrm{C}$ & 4.44 & 3.42 & 1.67 & 0.62 \\
\hline HS26 & 9.97 & 3.61 & 2.48 & 0.80 \\
\hline $\mathrm{LSD} 5 \%$ & 6.52 & NS & 1.98 & NS \\
\hline
\end{tabular}


character and to see if low shoot $\mathrm{Na}^{+}$content is correlated to survival and vigour in salt-stressed conditions.

Although a significant difference was found in shoot $\mathrm{Na}^{+}$content between Golden Promise and Maythorpe, this was not the case for root $\mathrm{Na}^{+}$content where there were no significant differences (Table 3 ). This result indicates that a sodium discrimination mechanism exists between the roots and shoots of Golden Promise. Root $\mathrm{Na}^{+}$content was found to be greater than that of the shoot measurement for all genotypes tested in $150 \mathrm{~mol} \mathrm{~m}^{-3} \mathrm{NaCl}$, except $H$. spontaneum HS26. HS26 was found to have the highest shoot $\mathrm{Na}^{+}$content of all the lines studied and lowest root $\mathrm{Na}^{+}$content; this line therefore has relatively little control in excluding sodium from shoot tissues. Data of shoot and root fresh weights of plants grown in 0 and $150 \mathrm{~mol} \mathrm{~m}^{-3}$ $\mathrm{NaCl}$ show little variation between Golden Promise and Maythorpe (Table 4). This suggests that the sodium exclusion mechanism of Golden Promise is independent of plant vigour which can be a confounding factor in salt tolerance studies (Richards, 1983; Forster et al., 1990).

\section{Acknowledgements}

The authors are very grateful to Professor E. Nevo, and Drs R. P. Ellis and M. Ambrose for supplying seed of the various barley lines, and to $\mathrm{Dr} \mathrm{D}$. Robinson for helpful comments. The work was funded by the Scottish Office Agricultural and Fisheries Department.

\section{References}

CHALMERS, K. J., WAUGH, R., WATTERS, J., FORSTER, B. P., NEVO, E., ABBOTT, R. J. AND POWELL, W. 1992. Grain isozyme and ribosomal DNA variability in Hordeum spontaneum populations from Israel. Theor. Appl. Genet., 84, 313-322.

FORSTER, B. P. 1992. Genetic engineering for stress tolerance in the Triticeae. In: Powell, W., Hillman, J. R. and Raven, J. A. (eds) Opportunities and Problems in Plant Biotechnology, Proc. R. Soc. Edinb., 99, 89-106.
FORSTER, B. P., PHILLIPS, M. S., MILLER, T. E., BAIRD, E. AND POWELL, W. 1990. Chromosome location of genes controlling tolerance to salt $(\mathrm{NaCl})$ and vigour in Hordeum vulgare and $H$. chilense. Heredity, 65, 99-107.

GILL, K. S. AND DUTT, S. K. 1987. Physiological aspects of salt tolerance in barley and wheat grown in pots in coastal saline conditions. Ind. J. Agric. Sci., 57, 409-415.

GORHAM, J., BUDREWICZ, E. AND WYN JONES, R. G. 1985. Salt tolerance in the Triticeae: growth and solute accumulation in leaves of Thinopyrum bessarabicum. J. Exp. Bot., 36, 1021-1031.

GREENWAY, H. AND MUNNS, R. 1980. Mechanisms of salt tolerance in non-halophytes. Ann. Rev. Pl. Physiol., 31, $149-190$.

MAAS, E. V., hOFFMAN, G. J. AND ASCE, E. 1977. Crop salt tolerance - current assessment. J. Irrig. Drain. Div. Proc. Am. Soc. Civil Engng, 103, 115-134.

RICHARDS, R. A. 1983. Should selection for yield in saline regions be made on saline or non-saline soils? Euphytica, 32, 431-438.

SIGURBJORNSSON, B. AND MICKE, A. 1969. Progress in mutation breeding. In: Induced Mutations in Plants. Proc. Symp. Nature, Induction and Utilization of Mutations in Plants, pp. 673-697. International Atomic Energy Agency, Vienna.

TAEB, M., KOEBNER, R. M. D., FORSTER, B. P. AND LAW, C. N. 1992. Association between genes controlling flowering time and shoot sodium accumulation in the Triticeae. Plant Soil, 146, 117-121.

THOMAS, W. T. B., ASHER, M. J. C., SWANSTON, J. S. AND THOMAS, C. E. 1988. The transfer of resistance to powdery mildew from Hordeum spontaneum to the spring barley cv. Golden Promise. In: Jorna, M. L. and Slootmaker, L. A. J. (eds) Cereal Breeding Related to Integrated Cereal Production. Proc. EUCARPIA Conf., pp. 200-204. Pudoc, Wageningen.

THOMAS, w. T. B., POWELL, w. AND SWANSTON, J. S. 1991. The effects of major genes on quantitatively varying characters in barley. IV. The GPert locus and quality characters. Heredity, 66, 381-389.

rHOMAS, W. T. B., POWELL, w. AND WOOD, w. 1984. The chromosomal location of the dwarfing gene present in the spring barley variety Golden Promise. Heredity, 53, 177-183. 